JPE (Jurnal Pendidikan Edutama) Vol. 8 No. 1 Januari 2021

P-ISSN : 2339-2258 (Print) E-ISSN: 2548-821X (Online)

http://ejurnal.ikippgribojonegoro.ac.id/index.php/JPE

\title{
PEMBELAJARAN INTERNAL DALAM MENDUKUNG KESUSKESAN WIRAUSAHA PEREMPUAN
}

\author{
Maretha Ika Prajawati \\ Jurusan Manajemen, UIN Maulana Malik Ibrahim Malang \\ email: marethaprajawati@gmail.com
}

\begin{abstract}
Entrepreneurial women are those who run a business innovatively, they are also very confident, creative and able to achieve economic independence both individually and collectively with others and increase their active role in economic activities. Entrepreneurship that exists within individuals arises from objective realities that exist in society, which will continue to develop and interact and acculturate so that it will create a new identity for the person concerned so that this raises questions and needs to be studied more deeply about the process of significance in the process. the lessons that women entrepreneurs take towards their business success. This research was conducted in an effort to comprehensively reveal the existence of women entrepreneurs in their activities by using a qualitative approach in order to obtain deeper results. The way in which women entrepreneurs experience the learning process is found in terms of internal locus of control. Learning is important in entrepreneurship, because entrepreneurship reflects the complex interactions between individuals and business situations that are always changing.
\end{abstract}

Key words: learning, success, entrepreneurship

\begin{abstract}
Abstrak: Perempuan wirausaha adalah mereka yang menjalankan bisnis dengan inovatif, mereka juga sangat percaya diri, kreatif dan mampu mencapai kemandirian dalam hal ekonomi baik secara individu maupun secara bersama sama dengan orang lain serta meningkatkan peran aktif dalam kegiatan ekonomi. Kewirausahaan yang ada dalam diri individu muncul dari realitas obyektif yang ada dalam masyarakat, yang akan terus berkembang dan berinterkasi serta berakulturisasi sehingga akan memunculkan identitas yang baru bagi yang bersangkutan sehingga hal ini menimbulkan pertanyaan serta perlu untuk dikaji lebih dalam tentang proses yang signifikansi di dalam proses pembelajaran yang dilakui oleh para wirausaha perempuan menuju pada kesuksesan bisnisnya. Penelitian ini dilakukan dalam upaya untuk dapat mengungkap secara komprehensif keberadaan wirausaha perempuan dalam aktivitas mereka dengan menggunakan pendekatan kualitatif agar didapatkan hasil yang lebih mendalam. Adapun cara bagaimana wirausaha perempuan mengalami proses pembelajaran ditemukan dari sisi locus of control internal. Pembelajaran penting dalam kewirausahaan, karena dalam kewiraushaan mencerminkan interkasi yang kompleks antara individu dan situasi bisnis yang selalu akan berubah.
\end{abstract}

Kata kunci: pembelajaran, kesuksesan, wirausaha 


\section{PENDAHULUAN}

Kewirausahaan merupakan salah satu faktor pendukung yang mampu mendorong penguatan ekonomi dan diharapkan dapat mengurangi jumlah pengangguran serta kemiskinan dengan peningkatan jumlah pengusaha. Jika jumlah kewirausahaan meningkat maka pertumbuhan ekonomi akan semakin baik pula. Wirausaha hadir di dalam mendukung pertumbuhan nasional akrena mampu menciptakan nilai tambah atas barang serta jasa, dapat mengurangi kesenjangan ekonomi serta sosial dan mampu menciptakan masyarakat yang adil serta makmur. Perkembangan kewirausahaan wanita akhir akhir ini semakin meningkat dan berkembang, salah satunya di Indonesia. Kewirasuahaan wanita hadir dan berpotensi sebagai motor penggerak dalam proses pemberdayaan perempuan dan transformasi sosial (Tambunan, 2012).

Perempuan wirausaha dapat didefinisikan sebagai perempuan yang memiliki dan menjalankan bisnis dengan inovatif, mereka juga sangat percaya diri, kreatif dan mampu mencapai kemandirian dalam hal ekonomi baik secara individu maupun secara bersama sama dengan orang lain, sehingga diharapkan dapat menghasilkan peluang kerja yang baru bagi orang lain (Terjesen \& Lloyd, 2015 dan Singh, 2018). Fenomena ini menjadi isu yang menarik dalam upaya pemberdayaan perempuan dan meningkatkan peran aktif dalam kegiatan ekonomi. Fenomena perempuan bekerja nampak pada keterlibatanya dalam beberapa bidang pekerjaan sebagai bentuk upaya mencari nafkah dan bertahan hidup (Hull, 1976). Perempuan terdorong untuk bekerja mencari nafkah pada umumnya dilatarbelakangi oleh tuntutan ekonomi dalam rumah tangga dan penghasilan dari suami yang tidak cukup untuk memenuhi kebutuhan keluarganya yang meningkat sedangkan pendapatan keluarga tidak selalu meningkat. Hal ini membuat perempuan ikut serta di dalam kegiatan mencari nafkah melalui kegiatan wirausaha. Fenomena ini menunjukkan bahwa terjadi pergeseran peran perempuan dalam bidang ekonomi, dimana perubahan budaya serta sistem sosial telah secara terbuka memberikan ruang bagi perempuan untuk berpartisipasi dalam kegiatan ekonomi serta kesetaraan sosial (social equality).

Ketika perempuan bekerja melalui kegiatan wirausaha, perempuan dapat menemukan kebebasan secara finansial dan mandiri yang dapat membantu meringankan pendapatan rumah tangga. Partisipasi wanita dalam kewirausahaan semakin meningkat akhir akhir ini, sehingga hal ini menuntut wanita dapat melakukan penyeimabngan (trade off) antara mencari nafkah dalam wirauasaha dengan perannya sebagai ibu rumah tangga (Fisher et al, 2014). Kewirausahaan akan memberikan kebebasan bagi perempuan untuk dapat mengendalikan waktu, tugas serta beban kerja mereka juga waktu pribadi mereka. Karanwati (2012) mengungkapkan, peran wanita yang semakin meningkat dalam kewirausahan disebabkan bukan akrena tidak adanya kesempatan kerja di luar tetapi karena bekerja sebagai wirausaha memberikan kebebasan serta lebih fleksibel.

Kegiatan kewirausahaan, dimana di dalamnya terdapat nilai nilai kepribadian serta nilai sosial akan dapat membentuk sikap serta perilaku para wirausaha perempuan yang merupakan sumber dari pengetahuan yang sifatnya selalu berkembang dinamis (Sapir, dkk, 2014). Franco \& Haase (2009) mengungkapkan bahwa kewirausahaan adalah pembelajar (learner) yang dalam kegiatannya selalu akan belajar dan belajar.

Dalam kewirausahaa, akan terjadi proses pembelajaran yang muncul sebagai sebuah proses akal untuk bertindak dan berkembang secara berbeda, melalui pengalaman kontekstual untuk menciptakan realitas yang baru dan membangun makna (Minniti \& Bygrave, 2011). Pembelajaran dalam kewirausahaan merupakan pembelajaran konstruktivis dimana di dalamnya terdapat proses perilaku serta adanya interaksi sosial. 
Dalam penelitian ini, proses belajar dalam kewirausahaan adalah pembelajaran informal yang banyak dan dapat dialami oleh setiap orang yang bersumber dari pengalaman kehidupan sehari hari serta berpusat pada dirinya sendiri sebagai pembelajar (learner centered). Pembelajaran dalam kewirausahaan merupakan proses belajar dari pengalaman kehidupan yang telah dialami dan menimpa dirinya secara sadar (Kuntoro, 2016). Pembelajaran penting dalam kewirausahaan, karena dalam kewiraushaan mencerminkan interkasi yang kompleks antara individu dan situasi bisnis yang selalu akan berubah (Chell, 2008 \& Kirzner, 1973). Kewirausahaan yang ada dalam diri individu muncul dari realitas obyektif yang ada dalam masyarakat, yang akan terus berkembang dan berinterkasi serta berakulturisasi sehingga akan memunculkan identitas yang baru bagi yang bersangkutan (Sapir dkk, 2014). Sehingga hal ini menimbulkan pertanyaan serta perlu untuk dikaji lebih dalam tentang proses yang signifikansi di dalam proses pembelajaran yang dilakui oleh para wirausaha perempuan menuju pada kesuksesan bisnisnya. Penelitian ini dilakukan dalam upaya untuk dapat mengungkap secara komprehensif keberadaan wirausaha perempuan dalam aktivitas mereka dengan menggunakan pendekatan kualitatif agar didapatkan hasil yang lebih mendalam.

\section{METODE PENELITIAN}

Penelitian ini menggunakan pendekatan kualitatif sebagai upaya untuk dapat mengungkap secara komprehensif dan mendalam keberadaan wirausaha perempuan serta proses pembelajaran yang dialami. Keberadaanya akan dapat diungkap melakui makna yang emndalam, yang diamati dari kondisi internal serta kondisi eskternal dalam beberapa aktivitas kewirausahaan yang dilakukan sehingga akan dapat memperoleh deskripsi yang jelas serta mendalam. Dalam penelitian ini, informan yang akan dijadikan partisipan adalah wirausaha perempuan yang memenuhi kriteria yang berada di Malang
Raya. Adapun kriteria dan tahapan dalam pemilihan infroman penelitian antara lain:

1. Penjaringan infromasi awal yang didapatkan dari informan kunci rekan seajwat, teman kerja, media elektronik serta dinas terkait.

2. Tahap selanjutnya adalah Observasi awal untuk menentukan calon informan adalah dengan cara melakukan screening sesuai dengan kriteria pengambilan sampel yang telah ditentukan.

3. Pada tahap ketiga, calon informan tersebut memenuhi kriteria untuk dijadikan informan kunci dalam penelitian. Setelah dilakukan penelitian secara mendalam sampai kepada informan ke 10, informasi yang diperoleh cenderung berulang-ulang sehingga sudah mencapai titik jenuh. Oleh karena itu, informan kunci dalam penelitian ini berjumah 10 orang

Pengumpulan data dalam penelitian ini dilakukan dengan menggunakan teknik pengumpulan data observasi, wawancara, dokumentasi serta image visual. Kriteria yang digunakan dalam keabsahan data adalah metode triangulasi, member checking dan external audit (Creswell, 2007). Proses analisis data dilakukan sebagai berikut:

1. Langkah pertama adalah menyiapkan dan mengorganisasikan data untuk dianalisis.

2. Langkah ini memberikan gambaran umum tentang informasi dan kesempatan untuk merenungkan makna secara menyeluruh, misalnya tentang gagasan umum apa yang para responden katakan, arah dari pernyataan informan, sampai pada sejauh mana kredibilitas dan penggunaan informasinya dapat digunakan.

3. Langkah ketiga adalah memulai pengkodean semua data. pengkodean dari jawaban. Adapun langkah yang dilakukan dalam pengkodean semua data adalah melakukan initial coding: line by line coding atas semua jawaban responden

4. Langkah selanjutnya adalah menggunakan proses pengkodean untuk menghasilkan 
deskripsi serta kategori atau tema untuk selanjutnya dianalisis. Tema-tema ini adalah yang muncul sebagai temuan utama dalam studi kualitatif dan sering digunakan sebagai judul di bagian temuan yang disebut dengan focused coding

5. Langkah kelima merupakan interpretasi dari beberapa tema (lengkap dengan ilustrasi spesifik, beberapa perspektif dari individu serta kutipan yang mendukung) atau interpretasi dengan tema yang saling berhubungan

Langkah terakhir dalam analisis data melibatkan pembuatan interpretasi dalam penelitian kualitatif terhadap temuan atau hasil

\section{HASIL DAN PEMBAHASAN}

Dalam pembelajaran terdiri dari kegiatan belajar dengan melakukan ada umpan balik yang semuanya bersifat alami (Minniti dan Bygrave, 2001; Politis, 2005). Pengalaman masa lalu dalam pengembangan berkelanjutan sebagai pendukung dalam proses pembelajaran kewirausahaan. Pembelajaran kewirausahaan adalah siklus yang berulang, di mana para pengusaha akan terus mengalaminya, dimana pengetahuan yang sebelumnya diperoleh dan akan memperoleh pengetahuan baru (Minniti dan Bygrave, 2001). Adapun cara bagaimana wirausaha perempuan mengalami proses pembelajaran dalam penelitian ini ditemukan hasil antara lain dapat dilihat dari sisi locus of control internal. Menurut Kustini (2005) mengungkapkan bahwa Locus of control adalah salah satu aspek kepribadian yang dimiliki oleh setiap individu, yang pada dasarnya menunjukkan pada keyakinan individu mengenai sumber penyebab dari peristiwa-peristiwa yang terjadi pada dirinya serta tingkat di mana individu yakin bahwa mereka adalah penentu nasib mereka sendiri (Kustini, 2005 dan Robbins, 2007) yang menunjuk pada keyakinan individu mengenai peristiwa-peristiwa yang terjadi dalam hidupnya. Locus of control adalah persepsi seseorang terhadap keberhasilan ataupun kegagalannya dalam melakukan berbagai kegiatan dalam hidupnya. Individu dengan
Locus of control internal mempunyai persepsi bahwa lingkungan dapat dikontrol oleh dirinya sehingga mampu melakukan perubahanperubahan sesuai dengan keinginannya, termasuk dalam menerapkan hasil pelatihan yang diperoleh ke dalam pekerjaannya. Karena individu merasa dapat mengontrol dirinya sendiri maka ada kecenderungan mempunyai keyakinan yang tinggi bahwa mereka mampu dalam menyerap isi program pelatihan sehingga selanjutnya dapat menerapkan hasil pelatihan tersebut ke dalam pekerjaan. Faktor internal individu yang di dalamnya mencakup kemampuan kerja, kepribadian, tindakan kerja yang berhubungan dengan keberhasilan bekerja, kepercayaan diri dan kegagalan kerja individu bukan disebabkan karena hubungan dengan mitra kerja. Locus of control internal dalam penelitian ini ditemukan antara lain time management (memanage dan mengolah waktu), human resource management (sumber daya manusia), hobby (mendalami hobi), innovation (inovasi), experience (pengalaman masa lalu) dan planning (perencanaan).

\section{A. Time Managament (Memanage Waktu)}

Kemampuan dalam menggunakan waktu dengan tepat, efektif, efisien, dan menguntungkan, merupakan suatu kewajiban yang harus dilakukan oleh para wirausaha. Dengan adanya waktu, segala sesuatu dapat terjadi, tetapi tanpa waktu maka tidak ada sesuatu yang akan terjadi. Pentingnya memiliki manajemen waktu dalam berbisnis menjadi salah satu faktor menuju kesuksesan. Dimana ketika seseorang menjalankan suatu bisnis maka ia harus menjalankan bisnisnya dengan penuh rasa tanggung jawab

Jika berbicara tentang waktu, maka waktu memainkan peran penting dalam kewirausahaan, mulai dari waktu pengambilan keputusan awal, kegiatan pertumbuhan, dan masuknya pasar ke manajemen waktu wirausaha, dianggap waktu dianggap sebagai sumber daya yang langka (Zachary et al., 2015). Aeon dan Aguinis (2017) mengemukakan bahwa bagaimana kita mengelola waktu akan mampu memengaruhi 
kesejahteraan. Manajemen waktu dapat diartikan sebagai suatu bentuk pengambilan keputusan yang digunakan oleh individu untuk menyusun dan menyesuaikan waktu mereka dengan kondisi yang selalu berubah. Dalam manajemen waktu maka dapat dilakukan penghitungan waktu secara sistematis dan mengalokasikan waktu secara lebih efisien di antara serangkaian tugas dan kegiatan yang diprioritaskan. Seperti dikemukakan oleh informan WN:

Dikatakan keterbatasan itu sebenarnya bagaimana cara kita mengolah atau memange waktu, memanage diri kita sendiri, keluarga.

Hasil penelitian menunjukkan bahwa manajemen waktu adalah bagian yang penting dalam kewirausahaan. Manajemen waktu merupakan proses pengorganisasian, perencanaan, dan penguasaan cara membagi waktu di antara kegiatan tertentu atau dengan kata lain merujuk pada pengelolaan waktu secara efektif sehingga waktu yang tepat dialokasikan untuk pekerjaan yang benar. Manajemen waktu yang baik akan memungkinkan kita dapat bekerja lebih cerdas daripada bekerja lebih keras sehingga kita dapat menyelesaikan lebih banyak pekerjaan dalam waktu yang lebih singkat. Manajemen waktu adalah faktor kunci untuk menjadi produktif secara efisien dan efektif.

\section{B. Human Resource Management (Sumber} Daya Manusia)

Manajemen sumber daya manusia dianggap sebagai kegiatan manajerial penting yang dapat mempengaruhi hasil dalam proses kewirausahaan (Morris \& Jones, 1993). Keberhasilan atau kegagalan dari kewirausahaan dapat dipastikan dan dipengaruhi oleh manajemen sumber daya manusia yang efektif (Katz et al., 2000). Sumber daya manusia sangat penting untuk keberhasilan kewirausahaan, oleh karena itu praktik sumber daya manusia harus fokus pada membangun hubungan antara karyawan.
Seperti yang dikemukakan oleh informan SH dan TZ:

Karna kalok saya menurut dengan pasar ini mati wes soalnya opo yo, harganya itu terus terang dundunan dan kualitas gak terjaga oleh karna itu SDM-nya kan macem-macem ya iku kudu dipertahankan.

Untuk yang keluar negeri itu spesifiknya hanya perlatan dapur jadi varian yang kita tambah ya varian piring, sendok jadi anak anak itu saya bagi, yang ahlinya motong, ahlinya ngalusno saya suruh proses jadi kebersamaan dan gotong royong itu

Dalam kewirausahaan perlu untuk mendorong pembangunan hubungan antara karyawan, antara karyawan dan organisasi dan antara karyawan dan pemangku kepentingan organisasi. Hal ini penting dilakukan untuk menjalin hubungan karena mereka mewakili saluran penting dalam aliran pengetahuan dan informasi, yang merupakan dasar pembangun inovasi dan peluang wirausaha dalam menjalankan bisnis.

Sumber daya manusia menjadi salah satu bidang keputusan manajerial yang penting yang mempengaruhi kewirausahaan (Kuratko et al., 2005). Sejumlah besar kebijakan terkait sumber daya manusia dapat memengaruhi kewirausahaan. Sumber daya manusia memainkan peran kunci dalam kewirausahaan sebagai penggerak dalam pengembangan dan pertumbuhan perusahaan (Sancez \& Soriano, 2011). Karyawan harus mampu berinovasi, mengambil risiko, dan bertukar pengetahuan, disertai dengan sistem penghargaan/ reward. Karyawan dianggap sebagai sumber daya penting untuk keberhasilan suatu perusahaan yang, oleh karena itu wirausaha harus mampu mengelola karyawannya (Barringer et al, 2005).

\section{Hobby (Mencintai Hobi)}

Dalam dunia bisnis saat ini yang selalu terus mengalami perubahan begitu cepat, tak jarang menuntut wirausaha untuk terus bekerja keras dan melakukan improvisasi terhadap 
bisnis yang dijalani. Mereka yang memiliki semangat dan selalu ingin mencoba hal baru dalam kehidupannya, pasti bisa terus bisa bertahan. Banyak pengusaha mampu memulai bisnis mereka sendiri. Kita mungkin bertanyatanya bagaimana mereka memutuskan bisnis apa yang akan dioperasikan. Banyak dari mereka bertindak berdasarkan ide atau peluang baru. Sebuah ide berbeda dari sebuah peluang. Peluang adalah kemungkinan yang muncul dari kondisi yang ada. Ide meripakan pemikiran atau konsep yang berasal dari pemikiran kreatif. Ide bisa datang dari berbagai macam sumber (Greene, 2007). Membuat daftar hobi dan minat dapat membantu kita memutuskan bisnis apa yang tepat untuk dijalankan. Seperti yang dikemukakan oleh informan SH dan DR:

Karena didasari dengan hobi ataupun sudah satu dengan hobi paling tidak, hobi itukan mesti dibiayai. Saya juga gitu, karna saya hobiya dipernak-pernik keterampilan itu saya hobi sekali

Gak ada ini nya gak ada di dunia seni tapi pekerjaan yang menyenangkan itukan hobi yang lumayan dan pekerjaan yang menyenangkan

Ide bisnis dapat berupa penemuan, produk atau layanan baru. Ide bisnis yang baik tidak harus berupa produk atau layanan yang unik. Mayoritas wirausaha menemukan ide-ide biasa yang luar biasa yang mampu memberikan nilai lebih besar kepada pelanggan. Salah satu cara untuk membangun bisnis adalah mengembangkan minat atau hobi pribadi, dimana mereka menemukan cara untuk mengubah hobi mereka menjadi bisnis yang sukses (Henriksson, 2013).

\section{Innovation (Inovasi)}

Perusahaan-perusahaan dari semua industri saat ini mengembangkan inovasi untuk menjamin keberhasilan mereka di pasar. Kemampuan inovasi dapat dikonseptualisasikan sebagai potensi untuk menciptakan novel dan produk atau pengetahuan yang berharga (Zheng, et al, 2010). Lawson dan Samson (2001) menentukan kapabilitas inovasi sebagai kemampuan untuk terus mengubah pengetahuan dan gagasan dalam produk, proses dan sistem baru untuk kepentingan perusahaan dan pemangku kepentingannya. Inovasi adalah penentu utama produktivitas dan pertumbuhan jangka panjang. Seperti dikemukakan oleh informan $\mathrm{SH}$ :

Kemampuan kerajinan kita kan harus di asah, ya kita harus inovasi, memperpanjang umur usaha ya dari inovasi tadi itu...

Berinovasi bagi seorang wirausaha merupakan kunci sukses. Inovasi merupakan tindakan kewirausahan untuk meraih sukses dalam persaingan usaha. Melalui penelitian dan pengembangan (research and development) para wirausahan menemukan kebaruan, kegunaan serta kemudahan sebagai nilai tambah dan daya saing.

Ahmed dan Shepherd (2010) menyatakan bahwa inovasi tidak hanya terbatas pada benda atau barang hasil produksi, tetapi juga mencakup sikap hidup, perilaku, atau gerakan-gerakan menuju proses perubahan di dalam segala bentuk tata kehidupan masyarakat. Seperti dikemukakan oleh Ibu DR :

Kami mencoba berinovasi tidak hanya menggunakan botol bekas, namun juga menggunakan toples, gelas dan bahkan piring

Inovasi dapat memberikan beberapa manfaat sebagai berikut: peningkatan kualitas hidup manusia melalui penemuan-penemuan baru yang membantu dalam proses pemenuhan kebutuhan hidup manusia; serta inovasi memungkinkan suatu perusahaan untuk meningkatkan penjualan dan keuntungan yang diperoleh. Proses inovasi mencakup kegiatan pengembangan dan implementasi. Pengembangan meliputi desain, pengembangan produk dan perencanaan proses inovasi dalam fase inovasi. Jadi fase pengembangan meliputi mengeluarkan ide dan 
pemecahan masalah, sedangkan implementasi meliputi kegiatan penerapan desain inovasi yang telah dibuat atau direncanakan.

\section{Experience (Belajar dari Pengalaman)}

Belajar merupakan suatu perubahan tingkah laku yang terjadi akibat dari stimulus yang diberikan kepada seseorang yang dapat terjadi dari pengalaman hidup seseorang. Seseorang dapat dikatakan belajar disaat mereka bisa mengetahui bagaimana cara untuk menyelesaikan suatu masalah yang sedang dihadapi. Belajar pun dapat muncul dari pengalaman pribadi wirausaha. Belajar merupakan sebuah proses, dimana seseorang dapat merubah pola piker serta tingkah lakunya agar menjadi lebih baik dari sebelumnya. Pengalaman dapat membimbing seseorang menuju pada jalan lebih baik. Pengalaman akan berharga bagi seseorang jika mereka mampu mengambil pelajaran dari pengalaman tersebut, namun jika tidak belajar maka seberapa banyak pelajaran tidak akan ada gunanya. Seperti dikemukakan oleh informan LF:

Sebelum saya jualan, kan saya juga sebagai pembeli, kita pergi ke matahrai, Ramayana lihat baju harganya 500 ribu, eh sebulan kemudian diskon 70\%. Nah hal secara psikologis membuat ibu ibu tidak percaya pada brand itu dan akhirnya besok besok aku tak beli nunggu dikson aja. Hal ini menjadi pembelajaran saya untuk menciptakan merek, menjaga kualitas serta untuk menjada psikologi dari customer, jangan sampai dia beli baju harga 1 juta, besok diskon $70 \%$ jadi 300. Karena kita kelas menengah jadi kalau banting setir ke harga segitu jadi ndak prestisius lagi, nanti orang semua bisa pakai.

Pengetahuan sebelumnya dan pembelajaran yang sedang berlangsung memeainkan peran penting bagi pelaku bisnis dalam menghadapi perubahan dan menciptakan ketrampilan untuk mengembangkan bisnis. Sebagian besar wirausaha pasti akan belajar dari pengalamannya. Wirausaha akan memadukan pengalaman yang didapatkan dengan pengetahuan yang mereka peroleh dari pengalaman itu. Dengan demikian dapat diasumsikan bahwa wirausaha berpengalaman akan memodifikasi mereka (Marti \& Smith, 2010). Bahkan Kolb (1984) mengatakan bahwa belajar adalah pengetahuan tentang masa depan.

\section{E. Planning (Membuat Perencanaan)}

Dalam setiap kegiatan yang kita lakukan, tentunya kita tidak ingin gagal. Berbagai cara dilakukan untuk dapat meminimalisir terjadinya kegagalan. Salah satu hal yang dapat dilakukan adalah dengan melakukan perencanaan. Dalam perencanaan, wirausaha harus memiliki konsep yang jelas tentang kegiatan yang akan dilakukan, tujuan dari kegiatan yang dilakukan serta manfaat yang akan diperoleh. Sebuah rencana dibuat agar pekerjaan yang dilakukan dapat lebih fokus berjalan menuju pada tujuan yang telah dutetapkan. Sehingga penting bagi wirausahwan untuk membuat perencaaan serta perhitungan yang matang, proses yang baik serta tujuan yang jelas. Perencanaan yang baik tidak perlu rumit, tetapi mampu membuat usaha yang dijalankan tetap fokus dalam berproses menuju tujuan yang telah ditetapkan. Perencanaan merupakan suatu proses menentukan hal hal yang ingin dicapai di masa yang akan datang serta strategi yang diperlukan untuk mencapai tujuan tersebut. Perencanaan dilakukans ecara terkoordinasi untuk mencapai tujuan dalam kurun waktu tertentu. Seperti dikemukakan oleh infroman LF:

Dan yang pasti harus selalu planning, tahun ini apa tahun depan apa.step by step proses mulai dari mengenal bahan, cara ngrumati penjahit penjahit saya biar bisa sesuai dengan apa yang saya mau

Dalam lingkungan yang dinamis,
tuntunan perkembangan usaha yang
berkelanjutan menuntut perusahaan harus
mampu bersaing. Setiap yang dilakukan dalam
bisnis harus terkait dengan masa depan bisnis.
Perencanaan merupakan salah satu dari


beberapa tindakan yang dapat dilakukan untuk masa depan bisnins. Drucker (1993) mengungkapkan bahwa perencaan haruslah menjadi inti dari setiap tindakan yang dilakukan. Proses perencanaan yang efektif dan dikelola dengan baik akan mampu mengarahkan semua sumber daya untuk menciptakan keterpaduan dan kesuksesan bisnis.

\section{SIMPULAN}

Belajar sepanjang waktu menjadi elemen sentral dari proses kewirausahaan. Wirausaha adalah sebagai pembelajar yang luar biasa yang belajar segalanya dari semua orang, terutama dari kegagalan selama proses menjalankan bisnis mereka. Kewirausahaan sebagai proses pembelajaran tanpa akhir, dimana dalam perjalanan bisnisnya mereka juga melakukan identifikasi peluang bisnis yang berkelanjutan. Adapun cara bagaimana wirausaha perempuan mengalami proses pembelajaran dapat dilihat dari sisi locus of control internal. Pembelajaran penting dalam kewirausahaan, karena dalam kewiraushaan mencerminkan interkasi yang kompleks antara individu dan situasi bisnis yang selalu akan berubah.

\section{DAFTAR RUJUKAN}

Aeon, B., Aguinis, H. (2017). It's about time: New perspectives and insights on time management. Academy of Management Perspectives, 31(4), 309-330.

Ahmed, P.K \& Shepherd, C. (2010). Innovation Management:Context, Strategies, System and Processes. Upper Saddle River: Pearson prentice hall.

Barringer, B.E., Jones, F.F., dan Neubaum, D.O. (2005). A quantitative content analysis of the characteristics of rapidgrowth firms and their founders. Journal of Business Venturing 20 (2005) 663687.

Bhat, I. H., \& Singh, S. (2018). Analyzing the moderating effect of entrepreneurship education on the antecedents of entrepreneurial intention. Journal of Entrepreneurship Education, 21(1), 1-10

Chell, E. (2008). The Entrepreneurial Personality. A Social Construction. The Second Edition. Routledge Taylor \& Francis Group.

Creswell, , John W., (2014). Research Design Qualitative, Quantitative Approaches and Mixed Methods. SAGE Publication, Inc. USA

Drucker, P. (1985). Innovation and Entrepreneurship: Practice and Principles. New York: Harper \& Row.

Drucker, P. F., (1995). Innovation and Entrepreneurship. Newyork: HarperCollins. P.28 Print

Fisher, G. (2012). Effectuation, causation, and bricolage: a behavioral comparison of emerging theories in entrepreneurship research. Entrepreneurship: Theory \& Practice, Vol. 36 No. 5, pp. 1019-1051.

Franco, M \& Haase, H. (2009). Entrepreneurship: An Organizatioal Learning Approach. Journal of Small Business and Entreprise Development. 16(4):

628-641. DOI: $\underline{10.1108 / 14626000911000965}$

Greene, J.C., (2008). Is Mixed Methods Social Inquiry a Distinctive Methodology?__Journal of Mixed Methods Research Volume 2 Number 1 January $2008 \quad 7-22$. $10.1177 / 1558689807309969$

Hull. V. (1976). Women in Java's Rural'sMiddleClass. Working Paper Series No.3. Population Institute Gadjah Mada University. Yogyakarta

Katz, J., Aldrich, H. E., Welbourne, T. M., \& Williams, P. M. (2000). Special issue on Human Resource Management and the SME: toward a new synthesis. Entrepreneurship: Theory and Practice, 25 (1), 7-10.

Kustini, Suharyadi, Fendy, 2004, "Analisis Pengaruh Locus of Control, Orientasi Tujuan Pembelajaran dan Lingkungan Kerja terhadap self Efficacy dan 
Transfer Pelatihan. Jurnal Ventura, Vol.7, No.1, April: 39-52.

Lawson, B., and Samson, D. (2001). Developing Innovation Capability in Organizations: A Dynamic Capabilities Approach. International Journal of Innovation Management, 5(3), 377- 400.

Minniti, M \& Bygrave, W. (2001). A Dynamic Model of Entrepreneurial Learnig. Entrepreneurship: Theory and Practice 25(3):5. April 2001. DOI: $\underline{10.1177 / 104225870102500301}$

Montoro-Sanchez, A., \& Soriano, D. R. (2011). Human resource management and corporate entrepreneurship. International Journal of Manpower, 32(1), pp. 6-13.

Morris, M.H. and Jones, F.F. (1993), "Human resource management practices and corporate entrepreneurship: an empirical assessment from the USA", The International Journal of Human Resource Management, Vol. 4 No. 4, pp. 873-96

Robbin, S.P., (2007). Prinsip-Prinsip Perilaku Organisasi. Jakarta: Edisi Kelima, Erlangga

Sapir, Pratikto, H., Hermawan, A.,Wasiti. (2014). Pembelajaran Kewirausahaan Berbasis Kearifan Lokal (Laporan Hasil Penelitian). Malang: LP2M Universitas Negeri Malang

Tambunan, Tulus. (2012). Usaha Mikro Kecil dan Menengah di Indonesia. Jakarta: LP3ES

Terjesen, S., and A. Lloyd. The 2015 Female Entrepreneurship Index. Washington, DC: Global Entrepreneurship Development Index

Zachary, M. A., Gianiodis, P.T \& Payne, T.G. (2014). Entry Timing: Enduring Lessons and Future Directions. Journal of management, December 18, 2014. https://doi.org/10.1177/01492063145639 $\underline{82}$

Zheng, Y., Naylor, L.A., Waldron, $\mathrm{S}$ and Oliver, D.M. (2019). Knowledge management across the environment- policy interface in China: What knowledge is exchanged, why, and how is this undertaken?. Environmental Science and Policy, 92 (2019) 66-75. 
124 JURNAL PENDIDIKAN EDUTAMA, Vol 8, No. 1, Januari 2021 